\title{
Social Capital and Collusion: The Case of Merchant Guilds*
}

\author{
Roberta Dessí ${ }^{\dagger}$ and Sheilagh Ogilvie \\ GREMAQ and IDEI, University of Toulouse \\ Faculty of Economics, University of Cambridge
}

September 6, 2003

\begin{abstract}
Merchant guilds have been portrayed as "social networks" that generated beneficial "social capital" by sustaining shared norms, effectively transmitting information, and successfully undertaking collective action. This social capital, it is claimed, benefited society as a whole because it offered a substitute for missing legal institutions, enabling medieval rulers to commit to provide a secure trading environment for alien merchants. But was this really the case? We develop an alternative model, in which merchant guilds emerge as a substitute for missing economic institutions (in particular, effective fiscal mechanisms), with radically different welfare implications. We show that the available historical evidence strongly supports our theory, and refutes existing models. In line with our theory, we find that merchant guilds used their social capital for socially harmful as well as beneficial ends.

Keywords: merchant guild, collusion, social capital, social networks, monopoly, taxation, rents.

${ }^{*}$ We would like to thank Dirk Bergemann, Jeremy Edwards, Guido Friebel, Tim Guinnane, Denis Hilton, Sven Rady, Klaus Schmidt, Jean Tirole, and seminar participants in Munich (CES) for helpful comments and suggestions.

${ }^{\dagger}$ IDEI, Université de Toulouse, Manufacture des Tabacs, Bât.F, 21 Allée de Brienne, 31000 Toulouse, France (dessi@cict.fr). http://www.idei.asso.fr

${ }^{\ddagger}$ Faculty of Economics, University of Cambridge, Sidgwick Avenue, Cambridge CB3 9DD, UK (Sheilagh.Ogilvie@econ.cam.ac.uk).http://www.econ.cam.ac.uk/faculty/ogilvie/index.htm.
\end{abstract}




\section{Introduction}

The merchant guild is unquestionably the most important historical institution adduced as evidence that social networks and "social capital" benefit the entire economy. ${ }^{1}$ It is therefore often used as a leading example by those advocating investment in social capital and social networks to solve problems of social exclusion and regional disparities in the rich West, economic transition in Eastern Europe, and development challenges in the Third World. Thus, for instance, in a speech to the World Bank, Joseph Stiglitz lists "guilds" among those institutions which, by generating social capital, could "support entrepreneurial efforts" in Eastern European transition economies. ${ }^{2}$ Robert Putnam identifies the social capital created by northern Italy's medieval guild tradition as a major determinant of its modern economic success, and argues that social capital produces "aggregate economic growth". ${ }^{3}$ Pranab Bardhan claims that merchant guilds have benefited commerce historically and urges more studies of how social capital can benefit commerce in modern developing economies. ${ }^{4}$ In a survey of social capital and economic development, Partha Dasgupta refers to the merchant guild as a social network whose social capital facilitated commercial growth. ${ }^{5}$

These views are based on a particular model of medieval European merchant guilds, advanced by Greif, Milgrom and Weingast (1994) (henceforth GMW). That model presents merchant guilds as institutions that facilitated information transmission, enforced shared norms and overcame obstacles to collective action, to the benefit of society as a whole. Specifically, GMW argue that "merchant guilds emerged during the late medieval period to allow rulers of trade centers to commit to the security of alien merchants", thereby "laying an important institutional foundation for the growing trade of that period". Their argument is based on the following idea. Individual merchants engaging in long-distance international trade faced high risks resulting from general commercial insecurity and arbitrary confiscations by rulers. Without a credible commitment by the ruler of a given trade center to provide a secure trading environment and himself refrain from confiscations, individual alien merchants might have been deterred from trading there. GMW show that if alien merchants belonged to an organization which could act in their collective interest and which had the power to enforce

\footnotetext{
${ }^{1}$ For definitions and discussion of the concept of social capital, see Bourdieu (1986); Coleman (1988, 1990); Dasgupta and Serageldin (2000); Glaeser, Laibson and Sacerdote (2002); Lin (2001); Ogilvie (2003); Putnam (2000); Putnam et al. (1993); Sobel (2002).

${ }^{2}$ Stiglitz (1999). On the relevance of merchant guilds and social capital to modern transition economies, see also Raiser (2001).

${ }^{3}$ Putnam et al. (1993); Putnam (2000).

${ }^{4}$ Bardhan (1996).

${ }^{5}$ Dasgupta (2000).
} 
compliance by each individual member, the ruler's commitment problem could be solved. In particular, the merchant organization could threaten a trade boycott if the ruler "misbehaved", and this (credible) threat could induce the ruler to behave well by providing security. GMW then argue that merchant guilds emerged with the support of alien rulers of trade centers in order to overcome their commitment problem. Although GMW was published in 1994, before "social capital" attained its current vogue in economics, it is easy to see why this has led so many economists to regard the merchant guild as an exemplar of social capital: these guilds fostered shared norms, transmitted information effectively, punished deviants swiftly, and organized collective action efficiently. And in GMW's story, they used this shared capital in ways that benefited the whole society.

But were merchant guilds really like this? In this paper, we demonstrate that the GMW model of merchant guilds is inconsistent with the historical evidence. We propose an alternative model which is borne out by the empirical findings. This model explains why merchant guilds arose in medieval Europe, how they evolved over time, and why they ultimately declined in some societies and survived in others. We show that merchant guilds indeed did generate social capital, but used it in ways that were not "social", in the sense of benefiting society as a whole. Merchant guilds harmed both non-members and the wider economy. We conclude that it is important to analyze the "dark side" of social capital.

We show in Section 2 that the GMW model of merchant guilds which has been widely accepted by economists is inconsistent with four important bodies of empirical evidence. First, the vast majority of merchant guilds were local associations of traders in a particular urban community, enjoying privileges from their local rulers. Only a minority were active in alien polities, and even these only enjoyed recognition from alien rulers by virtue of support by their own local rulers. This is inconsistent with the view that merchant guilds arose to overcome risks in long-distance trade arising from alien rulers' commitment problems. Second, far from reducing commercial insecurity in international trade centers, merchant guilds often created it by engaging in legal conflicts and violent struggles with other merchant guilds over economic privileges from rulers. Third, far from being able to enforce complete boycotts against offending rulers, most alien merchant guilds operated in international trade centers which contained half a dozen other merchant guilds; the inter-guild conflicts mentioned above made agreement on a joint boycott very unlikely if the ruler chose to discriminate against a particular guild, and severely limited the effectiveness of any unilateral boycott by a cheated guild. Fourth, merchant guilds obtained legal privileges from rulers granting them exclusive rights over trade, in return for which they rendered lump-sum transfers and other benefits to the rulers; the GMW model does not account for this universal feature of merchant guilds. 
We therefore need a new theory of the emergence and rise of merchant guilds, which must be able to account for the stylized facts just listed, notably merchant guilds' primarily local focus and rulers' willingness to grant them privileges, particularly monopoly rights over trade. This new model should also account for the stylized fact addressed by GMW, namely the willingness of rulers of international trade centers to welcome the establishment of alien guilds. As we shall see, all these stylized facts are closely related and can be understood within a single framework. The theory we propose identifies a key benefit which medieval rulers derived from the establishment of merchant organizations endowed with monopoly rights over local trade: these organizations enabled rulers to tax local trade much more efficiently. In the absence of merchant organizations, rulers would have had to delegate the collection of taxes on local trade to agents who would have been able to earn substantial rents from their superior knowledge of local conditions. By negotiating directly with merchant guilds, rulers were able to circumvent the need to give away a significant share of the total surplus from trade to third parties. Most importantly for rulers, merchant organizations, unlike tax collectors, could afford to "pay" ex ante for their ex-post informational rents. ${ }^{6}$

The ruler could therefore maximize his revenue from the taxation of local trade, as we demonstrate in Section 4, by requiring the guild to make regular fixed payments, in return for exemption from other forms of taxation, together with the legal right to exclude non-members from trade, to levy dues from members, and to sanction members who "misbehaved". There is ample historical evidence that this is exactly what took place. Our theory can therefore explain not only the emergence of merchant guilds, but also their relationship with rulers, including the specific privileges they were granted and the transfers they made in return.

Once a guild was established in a given city, enjoying local monopoly rights and considerable power, it clearly had an incentive to use that power to become entrenched, thereby increasing its bargaining power relative to the ruler. In Section 5 we consider the implications of this for the evolution of ruler-guild relations. We explain how this could generate support by rulers for alien merchant guilds, and why this often evoked considerable opposition from local merchant guilds. We also identify two further ways in which the establishment of merchant guilds benefited medieval rulers: first, by alleviating rulers' financial constraints, which could be severe (particularly in times of war); and second, by providing a countervailing power to that exercised by the landed nobility. We review the historical

\footnotetext{
${ }^{6}$ Individuals willing to act as tax collectors possessed very little capital as a rule, as shown by the historical evidence discussed in Section 3. Thus they could not have "paid" ex ante for their ex-post rents by making transfers to the ruler. The merchants themselves, on the other hand, typically possessed sufficient capital, by pooling their resources, to make the required payments to the ruler, as documented in Section 4.
} 
evidence on this, which strongly supports our analysis.

As Section 6 discusses, our model provides an account of merchant guilds that explains the historical evidence, including the differential pattern of guild decline, more satisfactorily than GMW. But it has very different implications. Merchant guilds did generate a "social capital" of shared norms, information transmission, effective sanctions, and collective action. But they used this social capital to secure rents for their members, at the expense of outsiders and the wider society. Our analysis of merchant guilds suggests strongly that social capital has negative, as well as positive, externalities.

The paper proceeds as follows. Section 2 reviews the historical evidence on merchant guilds and motivates our search for a new theoretical model. Section 3 presents the basic version of this model. Section 4 contains the main results, while Section 5 explores some extensions of the analysis. Section 6 presents our conclusions.

\section{The need for a new model of merchant guilds}

Four major bodies of empirical evidence cast doubt on the GMW model of merchant guilds which has hitherto been widely accepted by economists. This evidence motivates our search for an alternative model that can account for the available historical data. For reasons of space, only a few salient examples are highlighted in the text; references to the main body of evidence are given in the footnotes and in Dessí and Ogilvie (2003).

\subsection{Origins and evolution of merchant guilds}

The first body of evidence which contradicts the GMW theory is the fact that the vast majority of merchant guilds were local associations of the traders of a particular urban community, which initially obtained privileges from their local rulers. ${ }^{7}$ The origins of medieval merchant guilds are lost in the Dark Ages (c. 500 - c. 1000 $\mathrm{AD}$ ) because of a severe lack of documentation, although parallels are sometimes drawn with ancient Roman merchant collegia. Nevertheless it is clear that among the collegia, schola, and ministeria attested in the towns that survived the Dark Ages, and among the merchant "guilds" which emerged in old and new urban settlements alike from the eleventh century onward, local merchant organizations predominated. These were associations among the merchants of a particular locality, which initially obtained from their local rulers exclusive rights to practise certain types of local commercial activity. ${ }^{8}$ Although local trade left many fewer

\footnotetext{
${ }^{7}$ Bernard (1972); Dessí and Ogilvie (2003); Ehbrecht (1985); Schütt (1980).

${ }^{8}$ Bernard (1972); Ehbrecht (1985); Schütt (1980); Racine (1985).
} 
records and was much less glamorous than long-distance trade, it is now widely recognized as having made up a significant share of medieval European commerce, and hence as offering rents to those who could obtain monopolies within it. ${ }^{9}$ Most local merchant guilds never became important players in international trade - this was the case not only in the vast majority of smaller medieval cities, but also in many more important cities, including Paris and Rome. ${ }^{10}$ While most merchant guilds were not active in long-distance trade to any significant extent, all of them enjoyed considerable economic privileges in their own cities, including monopoly rights over local trade. ${ }^{11}$ Indeed, Bruges itself, the "undisputed fulcrum" of longdistance trade in northern Europe, had an exceptionally powerful merchant guild whose members drew their profits not from long-distance trade but from their "staple" rights through which they obliged alien merchants to trade through their sole intermediation. ${ }^{12}$

Only a minority of merchants, and only those from a minority of cities, expanded their operations beyond their own local area and traded in alien polities. ${ }^{13}$ These merchants often established "colonies" or "consulates" of their local merchant guild by obtaining legal recognition from an alien ruler. However, they succeeded in doing so only by virtue of their legal recognition by their own ruler as guilded merchants in their home city. For example, the merchant guild of Barcelona was able to obtain and keep its privileges from the rulers of Tunis and Alexandria between 1250 and 1264 only thanks to the recognition it enjoyed locally in Barcelona from King James I of Catalonia, and the diplomacy and military threats he was willing to exercise on its behalf with Muslim rulers. ${ }^{14}$

Even the famous "Hansas" of long-distance merchants were simply associations among the local merchant guilds of a number of cities for the purposes of foreign trade. ${ }^{15}$ The prime example is that of the German Hansa, an association among the merchant guilds of 70 north German, Dutch, and Baltic cities (with another 130 in looser association). There were also less important associations such as that formed by the merchant guilds of 17 Flemish and French towns in the thirteenth

\footnotetext{
${ }^{9}$ Abulafia (1995, 1997, 1999); Blockmans (2000); Bernard (1972); Epstein (1992); Spufford (2000); Theuerkauf (1996).

${ }^{10}$ See Bernard (1972) and Epstein (2000) on French cities; Hlavácek (2000) on Germanspeaking central Europe; Bahr (1911), Daenell (1905), Dollinger (1970) and Prevenier (2000) on the Low Countries; Johanek (1999) on Italy; Johanek (1999) and Laiou (2000) on the Byzantine Empire.

${ }^{11}$ Bernard (1972); Frölich (1934); Racine (1985).

${ }^{12}$ Prevenier (2000).

${ }^{13}$ Bahr (1911); Bernard (1972); Daenell (1905); Dollinger (1970); Epstein (2000); Hlavácek (2000); Johanek (1999); Laiou (2000); Prevenier (2000); Schultze (1985).

${ }^{14}$ On this example, see Abulafia (2000). See also Bernard (1972) on Italian merchant "colonies" in the Levant and Africa, and Hørby (1984) on Danish merchants in England.

${ }^{15}$ De Roover (1963); Planitz (1940); Reyerson (2000); Volckart and Mangels (1999).
} 
century, or the coalitions of the merchant guilds of certain Italian cities for the purposes of trading in France or the Levant. All "Hansas", however, were predated by their constituent local guilds and continued to derive their power and legitimacy from their recognition by local rulers in their localities of origin. ${ }^{16}$

Thus some local merchant guilds - though certainly a minority - formed "colonies" or joined "Hansas" abroad in order to transact in alien polities. But all local merchant guilds enjoyed privileges from their own local rulers over local trade. This is not consistent with GMW's theory that merchant guilds emerged and survived because they overcame problems of security in alien polities and problems of commitment faced by alien rulers.

\subsection{Commercial insecurity}

A second body of evidence casting doubt on the prevailing theory relates to the effect merchant guilds actually exerted on commercial insecurity. GMW argue that merchant guilds increased commercial security by enabling rulers to commit to provide a secure trading environment for alien merchants. Certainly, the privileges secured from alien rulers by long-distance merchants - both individually and as guilds - often included guarantees of security, along with reductions in tradetaxes and other commercial privileges. But there is no evidence that when these security guarantees were issued to guilds rather than individual merchants it actually had the effect of increasing the overall level of commercial security. The only support for this view is theoretical: it is contained in the GMW model, not in the evidence they present. Essentially it amounts to a counterfactual argument that the threat of guild boycotts increased rulers' incentives to enforce their security guarantees, and thus without merchant guilds insecurity would have been higher.

Hard evidence, by contrast, exists for the opposite view: namely, that merchant guilds were significant contributors to commercial insecurity. Most major centers of long-distance trade had several merchant guilds, and conflicts between them were a source of commercial insecurity for merchants. There were frequent violent conflicts in foreign cities among the guilds of rival alien merchants. ${ }^{17}$ Even more frequent were conflicts between a guild of alien merchants and the guild (or other organization) of the local merchants: many cases in which merchants operating in a foreign city were attacked by mobs, failed to obtain fair legal treatment, or suffered from acts of piracy occurred precisely because of rivalry with the local merchant guild over privileges from the ruler. ${ }^{18}$

\footnotetext{
${ }^{16}$ See Abulafia (1988); Bernard (1972), Blockmans (2000); Choroskevic (1996); Daenell (1905); De Roover (1963); Dollinger (1970); Hibbert (1963); Irsigler (1985); and Planitz (1940).

${ }^{17}$ On these, see Abulafia (1978, 1986); De Roover (1963); Greif et al. (1994); Pryor (2000); Reyerson (2000); and Smith (1940).

${ }^{18}$ On these, see Bahr (1911); Daenell (1905); Dollinger (1970); Lloyd (1991); Postan (1973);
} 
Indeed, one reason long-distance merchants so consistently asked alien rulers for security guarantees was precisely because they expected to be legally harrassed or violently attacked by local merchant guilds which regarded themselves as entitled to exclusive rights to trade in particular territories or particular lines of business. Part of the problem was due to the "incompleteness" of the "contracts" between rulers and merchant guilds: the legal privileges originally granted by rulers to local guilds typically did not specify with sufficient precision and detail the exact nature of their rights in all possible contingencies, which left significant scope for subsequent interpretation and conflict, as well as renegotiation between rulers and guilds.

Thus merchant organizations themselves, and the privileges granted to them by rulers, were often the source of - not the solution to - commercial insecurity.

\subsection{Non-viability of guild boycotts}

The theory of merchant guilds advanced by GMW depends crucially on the guild's assumed ability to enforce a complete boycott of trade with an alien ruler who "misbehaves". This may be a reasonable assumption for a single, monolithic guild endowed with coercive powers over its members, the case GMW consider in their model. But in practice most international trade centers had at least half a dozen alien guilds trading there. ${ }^{19}$ While each of these guilds was normally a "big" player (it accounted for a significant share of total trade in that center), the different guilds were typically competitors, as shown by the frequent conflicts between them already noted. Thus if a ruler chose to discriminate against a particular guild while maintaining good relations with the others, any initiative by the cheated guild to boycott trade would have been unlikely to be matched by the other guilds. When the Pisan merchant guild placed an embargo on Sicily in 1137 in response to confiscations by the ruler, the Genoese and Venetian merchant guilds continued to trade there. ${ }^{20}$ In the thirteenth and fourteenth centuries, when the Venetian merchants boycotted Alexandria and Beirut because of quarrels with the Sultans, the merchants of the "minor nations" kept the trade flowing. ${ }^{21}$ When the German Hansa boycotted Bruges in 1358 to put pressure on the ruler to maintain its privileges against the local merchant guild, smuggling by merchants both from individual Hansa cities and from non-Hansa cities weakened its impact. ${ }^{22}$

This is not to say that even a partial embargo on trade, by a sufficiently big player, would have been completely ineffectual. As discussed in Section 4.2,

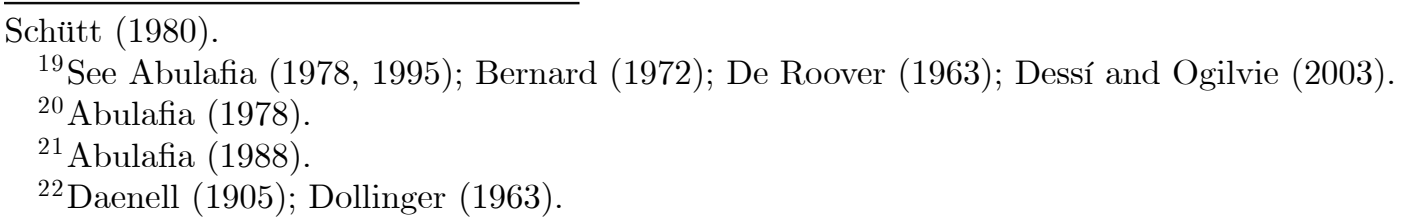


guilded merchants from a given location typically had monopoly rights over local trade in that location, including exports of locally produced goods. In those cases where locally produced goods had no close substitutes, the potential impact of competition with other guilds was considerably diminished. Thus the granting of monopoly rights over local trade by local rulers must have increased some guilds' bargaining power in their negotiations with alien rulers. However, in view of the evidence (noted above and discussed in detail in Section 4.3) on the very widespread granting of such monopoly rights to local merchant guilds, and the very limited role played by the majority of these guilds in international trade, we argue that the benefits in terms of increased bargaining power relative to alien rulers were a consequence of, and not the primary reason for, the formation of merchant guilds endowed with monopoly rights over local trade.

\subsection{Privileges and transfers}

Finally, the existing theory does not account for a universal feature of merchant guilds - namely, that they obtained monopoly privileges in exchange for payments to rulers. As richly documented below in Sections 4.3 and 5.2, both local and alien merchant guilds gave rulers lump-sum transfers, advantageous loans, military assistance, and other benefits. In return, rulers granted them a wide array of legal privileges enabling them to secure economic rents. ${ }^{23}$ Explaining this ubiquitous stylized fact is crucial to understanding the emergence and evolution of merchant guilds, and their implications for the well-being of the societies in which they were embedded.

\section{The model}

The prevailing GMW model of merchant guilds is thus inconsistent with major bodies of empirical evidence. Here we propose an alternative theory of merchant guilds, which can account for the available historical evidence. The theory identifies a key benefit which medieval rulers derived from the establishment of merchant organizations endowed with monopoly rights over local trade: these organizations enabled rulers to tax local trade much more efficiently.

This section introduces the simplest version of our model; several extensions are examined in Sections 4 and 5. We consider a medieval polity with four types of player: a ruler, merchants, consumers, and a tax collector. For simplicity, we assume that all players are risk-neutral.

\footnotetext{
${ }^{23}$ For a discussion of this evidence, see Dessí and Ogilvie (2003).
} 


\subsection{Merchants}

There is a large number $X$ of small identical individual merchants who can sell a homogeneous good at a cost $c>0$ per unit of the good. The set of all merchants is denoted by $A$. Each merchant is endowed with capital $K>0$.

\subsection{Consumers}

Consumers are represented by the inverse demand function for the good, given by $P(\theta, q) \equiv \theta(a-b q)$, where $a$ and $b$ are positive constants $(a>0, b>0)$, while $\theta$ is a random variable taking the value $\theta_{L}$ with probability $\pi$ and the value $\theta_{H}$ with probability $1-\pi\left(\theta_{H}>\theta_{L}>0\right)$. Thus $\theta$ represents a variety of possible factors affecting local demand, including income and preference shocks linked, for example, to changes in demographic and environmental conditions (e.g. disease, weather, pests). This formulation has the advantage of capturing in an extremely simple and parsimonious way the importance of "local conditions", which are observed either not at all or only imperfectly by the ruler.

\subsection{The ruler}

The ruler governs the polity: he provides certain public goods, such as law enforcement and defence, and finances these with various sources of revenue, including the taxation of trade. For the purpose of our analysis it is sufficient to treat his expenditures and his other sources of revenue as given exogenously, and to focus on the revenue he can raise from the taxation of local trade. We assume that the ruler's objective is simply to maximize his revenues from this source. This can be justified by noting that, during the historical period we are considering, consumer welfare had relatively little weight in the typical ruler's preferences, subject only to the constraint that it should not fall so low as to provoke a popular revolt. We can then think of the taxation of the one good in our model as representing the taxation of all those commodities for which this constraint was not binding.

We assume that the ruler has the power to tax trade, ${ }^{24}$ and to grant economic privileges to merchants; these privileges are discussed in greater detail below.

\subsection{The tax collector}

The tax collector is an agent who can be hired by the ruler to impose and collect an ad valorem tax on trade $\tau$. The agent, unlike the ruler, can observe the

\footnotetext{
${ }^{24}$ This assumption is consistent with the historical evidence: medieval rulers were able to tax trade through the imposition of ad valorem taxes such as tolls, purchase taxes, staples, brokerage dues, anchorage, cranage, and keelage. See Bernard (1972); Bisson (1984); Dessí and Ogilvie (2003); and Reyerson (2000).
} 
state of nature, $\theta$, and make the tax rate depend on it. We assume that the tax collector, being a single agent and not wealthy, is endowed with very little capital, which is normalized to zero. The zero capital assumption is made purely for expositional simplicity, as will become clear in Section 4: all we need for our results is that the tax collector be capital-constrained. This assumption is motivated by the historical evidence. In twelfth-century Catalonia, for instance, rulers appointed as local tax-gatherers "vicars", "bailiffs", and "saigs", recruited from the ranks of minor knights, unimportant creditors, local notables, priests, agrarian entrepreneurs, even working peasants. All of these agents were capitalconstrained. ${ }^{25}$ Sometimes rulers sold the right to collect certain taxes to wealthy "tax farmers", but this simply transferred to the tax farmers the problem of delegating tax collection, and was presumably reflected in the purchase "price" they were willing to pay.

\subsection{Information}

To summarize, our key informational assumption is the following: consumers, merchants, and the tax collector (if hired) are aware of local conditions $(\theta)$, but these are not observed by the ruler.

The historical importance of the information asymmetry between rulers and other agents concerning fiscally relevant data is well documented. Medieval rulers did not possess a civil service which could be trusted to provide accurate information on local fiscal conditions of which consumers and merchants were aware, but rather employed a variety of agents who proved, to a greater or lesser degree, unreliable. $^{26}$

\subsection{Timing}

The timing of the model is as follows:

- at $t=0$, the ruler decides whether to grant recognition to a merchant guild (see the detailed discussion in Section 4 below) and whether to hire an agent as tax collector. Ex ante transfers between the ruler and the guild or the agent, if any, take place at this stage.

\footnotetext{
${ }^{25}$ Bisson (1984). See also Blockmans (2000) and Fryde (1958) for evidence on the socioeconomic origins of the men appointed to collect taxes by the the thirteenth-century Counts of Flanders and the fourteenth-century kings of England, which further supports our assumption of capital-constrained tax collectors.

${ }^{26}$ The fiscal accounts of medieval Catalonia, for instance, show an unceasing struggle on the part of the Count-Kings to recruit more reliable agents to impose and collect taxes, and to devise more effective mechanisms for controlling the frequent fiscal malfeasance of their castellans, vicars, bailiffs, and saigs, resulting from the latter's superior information about local conditions. See Bisson (1984), and the discussion in Dessí and Ogilvie (2003).
} 
- at $t=1$, the state of nature $\theta$ is realized. Trade takes place and taxes, if any, are levied. Ex post transfers between the ruler and the guild or the agent, if any, take place after trade.

\subsection{Bargaining power}

We assume that the ruler has all the bargaining power at $t=0$. Thus if he hires an agent to collect taxes, he can do so by making him a take-it-or-leave-it offer. Indeed, it seems likely that an agent (ordinary individual) who refused the ruler's offer to work for him would have incurred some explicit and/or implicit sanction; moreover, the ruler could easily have found another agent willing to accept the offer. Similarly if the ruler decides to establish a subset of merchants as a merchant guild with a given set of privileges and obligations, he can do so by making them a take-it-or-leave-it offer. Merchants, before becoming organized in guilds, would have been in a poor position to exercise bargaining power in negotiating with the ruler. ${ }^{27}$

\section{Trade and taxation in the basic model}

We begin by considering what the ruler can achieve when merchants are not organized in a guild, then proceed to examine the role of guilds.

\subsection{Trade and taxation in the absence of merchant guilds}

In the absence of merchant organizations, the ruler cannot negotiate directly with each merchant, as this would imply prohibitively high transactions costs. ${ }^{28} \mathrm{He}$ therefore has to delegate tax collection to an agent who, unlike the ruler, can observe local conditions $(\theta)$, as well as realized trade (quantities and price). The agent is given the power to impose and collect an ad valorem tax $\tau$ : that is, for each unit of the good sold at price $P$, the tax collector takes $\tau P$ and the merchant is left with $(1-\tau) P$. In order to maximize tax revenue in each state of nature, the tax rate $\tau$ should depend on $\theta$. The revenue-maximizing state-contingent tax

\footnotetext{
${ }^{27}$ Thus, for instance, the merchants of Lombard and Carolingian Italy in the period c. 600 c. 1100 were only able to trade because they obtained privileges from the royal court, landowning nobles, or princes of the church; they were not yet able to form autonomous corporate organizations, and instead were heavily dependent on royal or aristocratic favour. See Racine (1985).

${ }^{28}$ The historical evidence suggests that before the appearance of merchant guilds, rulers did negotiate with individual merchants, but it was only worthwhile their incurring the costs to do so with the richest few; merchants operating on a smaller scale would yield too few taxes to be worth negotiating with. For suggestive evidence to this effect, see Abulafia (1978) and Racine (1985).
} 
rate $\tau^{*}(\theta)$, as well as equilibrium prices, trade levels and total tax revenues, are given by the following Proposition.

Proposition 1 When individual merchants are not organized in guilds, the ad valorem tax on trade $\tau^{*}(\theta)$ which maximizes tax revenue in each state of nature, is given by $\tau^{*}(\theta)=(a \theta-c) /(a \theta+c)$. When the tax rate is $\tau^{*}(\theta)$, equilibrium levels of trade, prices and total tax revenues are equal to $q^{*}(\theta)=(a-c / \theta) / 2 b$, $P\left(q^{*}(\theta), \theta\right)=(a \theta+c) / 2, T^{*}(\theta)=\tau^{*} P^{*} q^{*}=(a \theta-c)(a-c / \theta) / 4 b$.

Proof: see Appendix.

As might be expected, the revenue-maximizing tax rate, as well as the equilibrium price and quantity traded, and hence total tax revenues, are higher in the "good" state $\left(\theta_{H}\right)$.

The problem for the ruler is that, unlike the agent, he is not able accurately to observe either the state $\theta$, or the realized levels of trade $\left(q^{*}\right)$, or prices $\left(P^{*}\right)$. In what follows, we consider two possibilities. To begin with, we assume that the ruler can observe the tax rate $\tau$ applied by the agent. We consider this case because it might have been possible for the ruler, at relatively low cost, to check (e.g. through occasional random inspections) whether the agent was applying the tax rate $\tau$ rather than any arbitrary tax rate. However, as discussed below, there are also good reasons to think that the ruler would have found it difficult to observe the "true" tax rate applied by the tax collector. We shall therefore also examine the case where the ruler cannot observe $\tau$ : delegating taxation in this case is even more costly for him, which only strengthens our results. But for now, assume the ruler can observe the tax rate $\tau$ applied by the agent.

Thus the agent cannot simply apply a high tax rate and claim that he is applying the low tax rate. However, he can claim that the state is "bad" $\left(\theta_{L}\right)$ even when in fact the state is "good" $\left(\theta_{H}\right)$. This is enough for him to capture some rents, as shown in Proposition 2 below. Denote by $T^{\circ}(\tau, \theta)$ the total tax revenue that the agent can collect in state $\theta$ by applying the tax rate $\tau$.

Proposition 2 Assume that the ruler can observe the tax rate $\tau$ applied by the agent, but cannot observe the true state of nature $\theta$, realized levels of trade, prices, or tax revenues. In this case the second-best agreement between the ruler and the agent will specify the following:

(a) the tax rate to be applied in state $\theta_{H}, \tau^{\circ}\left(\theta_{H}\right)=\tau^{*}\left(\theta_{H}\right)$;

(b) the tax rate to be applied in state $\theta_{L}, \tau^{\circ}\left(\theta_{L}\right)=(\pi a-\alpha c) /(\pi a+\alpha c)<\tau^{*}\left(\theta_{L}\right)$, where $\alpha=1 / \theta_{L}-(1-\pi) / \theta_{H}$;

(c) the transfer the agent should make to the ruler in state $\theta_{H}, t\left(\theta_{H}\right)=$ $T^{\circ}\left(\tau^{\circ}\left(\theta_{H}\right), \theta_{H}\right)-T^{\circ}\left(\tau^{\circ}\left(\theta_{L}\right), \theta_{H}\right)+T^{\circ}\left(\tau^{\circ}\left(\theta_{L}\right), \theta_{L}\right)<T^{*}\left(\theta_{H}\right) ;$

(d) the transfer the agent should make to the ruler in state $\theta_{L}, t\left(\theta_{L}\right)=$ $T^{\circ}\left(\tau^{\circ}\left(\theta_{L}\right), \theta_{L}\right)<T^{*}\left(\theta_{L}\right)$. 
The ruler's expected utility from this agreement is given by $U^{D M}=\pi T^{\circ}\left(\tau_{L}, \theta_{L}\right)+$ $(1-\pi)\left[T^{\circ}\left(\tau_{H}, \theta_{H}\right)-T^{\circ}\left(\tau_{L}, \theta_{H}\right)+T^{\circ}\left(\tau_{L}, \theta_{L}\right)\right]$.

Proof: see Appendix.

The intuition for this result is the following. If the ruler simply required the agent to pay him a transfer equal to the maximum (first-best) tax revenues that can be collected in each state (i.e. $T^{*}\left(\theta_{H}\right)$ in state $\theta_{H}$ and $T^{*}\left(\theta_{L}\right)$ in state $\left.\theta_{L}\right)$, the agent would have an incentive to cheat in state $\theta_{H}$, claiming that the state was $\theta_{L}$, even though he would then be obliged to apply the lower tax rate, $\tau^{*}\left(\theta_{L}\right)$. By doing so, he could earn strictly positive rents; moreover, this outcome would be very inefficient from the point of view of the ruler-agent coalition, since the lower tax rate would be applied all the time, even in the good state when a higher tax rate is much more profitable. Proposition 2 describes the second-best outcome, taking into account the constraint due to asymmetric information between the ruler and the agent. As is well-known in standard adverse selection models of this kind, the second-best outcome entails no distortion in the "good" state, implying that the tax rate is set at its first-best level, whereas there is a distortion in the "bad" state, implying that the tax rate is set at a level strictly below the first-best: this is needed to discourage cheating, by making it very costly to claim that the state is $\theta_{L}$ when in fact it is $\theta_{H}$.

We can compare this second-best outcome with the first-best outcome, defined from the ruler's point of view; that is, the outcome in which tax revenues are maximized in each state and entirely appropriated by the ruler. In this case, the ruler's expected utility is given by $U^{F B}=\pi T^{\circ}\left(\tau_{L}^{*}, \theta_{L}\right)+(1-\pi) T^{\circ}\left(\tau_{H}^{*}, \theta_{H}\right)>U^{D M}$. The second-best outcome entails a loss for the ruler, for two reasons: first, because total tax revenues are "too low" in the bad state; second, because even in the good state, although tax revenues are maximized, the ruler receives only a fraction of them - the remainder is kept by the agent, and represents the agent's informational rents.

If we now relax the assumption that the ruler can observe the tax rate applied by the tax collector, the loss relative to the first-best outcome is correspondingly greater. The best the ruler can do in this case is to set the transfer $t=T^{*}\left(\theta_{L}\right)$, irrespective of the state $\theta$. Why would the ruler be unable to observe the tax rate applied, even allowing for the possibility of random checks suggested earlier? Given the second-best scheme described by Proposition 2, the agent may be tempted to collude with merchants in the "good" state, applying the lower tax rate in exchange for a bribe. If such collusion is difficult to detect, the ruler will always receive the lower transfer, $t\left(\theta_{L}\right)=T^{\circ}\left(\tau^{\circ}\left(\theta_{L}\right), \theta_{L}\right)<T^{*}\left(\theta_{L}\right)$. Thus a scheme in which the transfer is set equal to $t=T^{*}\left(\theta_{L}\right)$, irrespective of the state $\theta$, will be preferred by the ruler.

Could the ruler ever achieve the first-best with delegated taxation? One simple 
way to solve the ruler's problem, if the agent had sufficient capital ex ante, would be for the agent to purchase the right to tax the merchants. He could then set the revenue-maximizing tax rate in each state of nature, $\tau^{*}(\theta)$. A simple contract that would work (while minimizing the need for ex ante capital) is the following: ${ }^{29}$ ex ante (at $t=0)$, the agent makes a payment $L$ to the ruler, where $L=(1-\pi)\left[T^{*}\left(\theta_{H}\right)-T^{*}\left(\theta_{L}\right)\right]$

ex post (at $t=1$ ), after he has collected tax revenues, the agent makes a second payment to the ruler, of value $T^{*}\left(\theta_{L}\right)$.

However, we have assumed that the agent has insufficient capital ex ante, and therefore cannot pay $L$. As we saw earlier, the assumption that the agent is capital-constrained is consistent with available evidence on the socioeconomic origins of the men appointed to collect taxes by medieval rulers such as the twelfthand thirteenth-century Count-Kings of Catalonia, the thirteenth-century Counts of Flanders, and the fourteenth-century kings of England. This is where the establishment of a merchant guild can benefit the ruler, as will now be discussed.

\subsection{Merchant guilds: trade, taxation and privileges}

A possible solution to the ruler's problem, enabling him to achieve the first-best, is the following. A subset of merchants $S$ organize themselves as a group, able to act in the group members' collective interest: call this group "the guild". The guild pays $L$ to the ruler ex ante and $T^{*}\left(\theta_{L}\right)$ once trade has occurred, and is exempted from paying any other taxes.

Under what conditions can the guild be organized so as to implement the firstbest solution? The answer to this question will shed light on the privileges that the ruler will be willing to grant to the guild. Clearly, the guild needs to be able to:

(a) enforce the profit-maximizing levels of trade, $q^{*}(\theta)$, and prices, $P^{*}(\theta)$. In particular, this means preventing non-members from trading, or obliging them to trade with guild members and not directly with consumers (so that the guild can earn monopoly profits from trade), and ensuring that individual members do not deviate from the group norms established to promote their collective interest (for example, by trading at prices below $P^{*}(\theta)$ ).

(b) levy dues on members, so as to make the required payments to the ruler.

We therefore have the following result: ${ }^{30}$

\footnotetext{
${ }^{29}$ This assumes that the ruler can commit not to "steal" $L$ and then hire another agent to collect taxes - e.g. for reputational reasons.

${ }^{30}$ This result assumes implicitly that the ruler can commit not to "cheat" the guild by accepting the payment $L$ at $t=0$ and then withdrawing its privileges and hiring an agent to levy taxes at $t=1$. Section 5 will examine under what conditions the ruler can make such a (credible) commitment in a repeated game setting.
} 
Proposition 3 As long as $K X \geq L$, the ruler can achieve the first-best outcome, which gives him expected utility $U^{F B}$, by establishing a merchant guild endowed with monopoly rights over local trade, and the right to levy duties on its members. The guild makes a transfer of value $L$ to the ruler ex ante and another transfer of value $T^{*}\left(\theta_{L}\right)$ ex post.

Proof: The ruler at $t=0$ makes a take-it-or-leave-it offer to a subset of merchants $S$, requiring them to pay $L$ ex ante and $T^{*}\left(\theta_{L}\right)$ ex post. In return, the ruler establishes them as a merchant guild with monopoly rights over local trade and the right to levy duties on members; moreover, he exempts them from other forms of taxation. Since $K X \geq L$, the ruler can always find a subset of merchants $S$ endowed with sufficient capital to accept the offer and make the required ex ante payment.

This model of the formation of merchant guilds has five key empirical implications. We should find that:

(1) Rulers were willing to establish and support local merchant guilds, and endow them with monopoly rights over local trade. These monopoly rights might take different forms, including the right to exclude non-members from trade altogether, as well as the requirement for non-members to trade only with members of the guild, or using guild members as intermediaries.

(2) Local merchant guilds established norms to promote their collective interest, particularly relating to prices, volume of trade, transactions with nonmembers, etc.

(3) Local merchant guilds were able to impose sanctions to ensure that their members did not deviate from these norms.

(4) Local merchant guilds were able to levy dues from their members, which were used, at least partly, to make transfers to the ruler.

(5) Local merchant guilds were granted exemptions from other forms of taxation by the ruler.

The historical evidence strongly supports all five of these implications of our model.

\subsection{Historical evidence in support of our model}

We now review some of the abundant historical evidence which supports the five key implications outlined above; a wealth of additional examples can be found in Dessí and Ogilvie (2003).

(1) Rulers were willing to establish and support local merchant guilds, and endow them with monopoly rights over local trade. From the late Dark Ages on, we know about merchant guilds precisely because of the legal recognition they were 
granted in charters from rulers, often alongside a variety of privileges. ${ }^{31}$ Among the most important of these privileges were a wide array of powers enabling them to exclude and discriminate against alien merchants. ${ }^{32}$ Thus in most medieval European towns, non-local merchants had to submit to so-called "rights of staple", which required them to unload their wares in municipal warehouses where members of the local merchant guild had the right to purchase them at privileged prices. ${ }^{33}$ Alien merchants also had to pay special tolls and taxes from which the local merchant guild was exempt. ${ }^{34}$ In most cities, the local merchant guild also enjoyed rights of brokerage, which forbade alien merchants from trading directly with one another or with local customers, obliging them instead to trade through local brokers who were appointed by the local merchant guild from its own membership. ${ }^{35}$

Local merchant guilds also enjoyed legal privileges enabling them to exclude from trade local individuals who were not members of the guild. Furthermore, they were able to impose significant restrictions on guild membership by making admission contingent on a range of requirements, including approval by a sufficient proportion of existing members, payment of entry fees (sometimes set at prohibitively high levels for particular categories, e.g. craftsmen), satisfaction of catch-all "reputation clauses", and requirements based on gender, ethnicity, religion, residence, citizenship, and property ownership. ${ }^{36}$

(2) Local merchant guilds established norms to ensure that guild members enjoyed rents. Medieval merchant guilds "submitted themselves to certain common rules with regard to prices, quantities, chartering and lading, the organisation of convoys and disputes between members of the group". ${ }^{37}$ Indeed, guild norms often went beyond purely economic rules: the statutes of a French guild, dating from the second half of the eleventh century, declared that "a foreign merchant

\footnotetext{
${ }^{31}$ See, for instance, Blockmans (2000); Choroskevic (1996); De Roover (1963); Frölich (1934); Kuske (1939); Volckart and Mangels (1999).

${ }^{32}$ See Dessí and Ogilvie (2003); Hibbert (1963); Irsigler (1985); Leguay (2000); Postan (1973); Reyerson (2000); Schultze (1908); Spufford (2000).

${ }^{33}$ Bernard (1972); Kuske (1939); Reyerson (2000); Schultze (1908); Volckart and Mangels (1999).

${ }^{34}$ Bernard (1972); Schultze (1908); Volckart and Mangels (1999).

${ }^{35}$ Bernard (1972); Choroskevic (1996); Hibbert (1963); Schultze (1908); Spufford (2000).

${ }^{36}$ See Dessí and Ogilvie (2003); Dilcher (1985); Ehbrecht (1985); Epstein (2000); Hibbert (1963); Leguay (2000); Planitz (1940); Postan (1973); Racine (1985); Reyerson (2000); Schultze (1908); Schulz (1985); Schütt (1980); Smith (1940).

${ }^{37}$ Bernard (1972). For specific examples of norms fostered by merchant guilds to secure rents for their members, see Daenell (1905); De Roover (1963); Dessí and Ogilvie (2003); Fryde (1985); Hoffmann (1980); Irsigler (1985); Planitz (1940); Prevenier (2000); Schütt (1980); Smith (1940); Volckart and Mangels (1999).
} 
who was the enemy of one member was to be treated as the enemy of all". ${ }^{38}$ Thus merchant guilds did create a social capital of "shared norms", but these norms were used to secure rents for network insiders at the expense of others.

(3) Local merchant guilds imposed sanctions on members who violated their norms. These sanctions typically took the form of fines and confiscations, and occasionally more extreme forms, such as imprisonment, shaving, flogging, or expulsion from the guild. ${ }^{39}$ Thus in the thirteenth century the Leicester merchant guild threatened expulsion for any member who did business with a certain Flemish merchant who had violated the guild's monopoly over the wool trade in the surrounding countryside, ${ }^{40}$ while the merchant guilds of tenth-century Constantinople imposed penalties of flogging, shaving, or confiscation on any member or outsider who violated their by-laws. ${ }^{41}$

(4) Local merchant guilds were able to levy dues from their members, and used them at least partly to make transfers to the ruler. Dues included entry fees, various types of license fee (e.g. the silk-merchants' guild of tenth-century Constantinople levied a license fee on all members who bought workshops, which was delivered to the political authorities), ${ }^{42}$ and regular (e.g. annual) membership dues. ${ }^{43}$ Transfers to the ruler were usually made as lump-sum payments, but they could also take the form of advantageous loans (as discussed in Section 5.3). ${ }^{44}$ Thus, for instance, Spanish merchant guilds routinely made contributions to rulers to finance warfare, getting "a quid pro quo in the form of renewal and enlargement of the guild privileges ... it was the rule rather than the exception for the Consulado to pay substantial sums for privileges and other favors granted by the crown". ${ }^{45}$

(5) In return, the local merchant guild was often exempted from other forms of taxation by the ruler. Indeed, freedom from customs, tolls, and trade-taxes was one of the most universal of the privileges rulers conferred on merchant guilds. ${ }^{46}$

\footnotetext{
${ }^{38}$ Volckart and Mangels (1999), citing Planitz (1940).

${ }^{39}$ Choroskevic (1996); Dessí and Ogilvie (2003); Freshfield (1938); González de Lara (1991); Planitz (1940); Racine (1985); Schulze (1985); Schütt (1980).

${ }^{40}$ Bateson (1899).

${ }^{41}$ Freshfield (1938), Racine (1985).

${ }^{42}$ Freshfield (1938); Racine (1985).

${ }^{43}$ See Dessí and Ogilvie (2003); Schütt (1980); Smith (1940); Volckart and Mangels (1999).

${ }^{44}$ See, e.g., Dessí and Ogilvie (2003); Klein (1932); Kuske (1939); Pryor (2000); Racine (1985); Schütt (1980); Smith (1940).

${ }^{45}$ Smith (1940).

${ }^{46}$ As pointed out by Planitz (1940); for examples, see Dessí and Ogilvie (2003); Ehbrecht (1985); Hoffmann (1980); Volckart and Mangels (1999).
} 


\section{Some further implications and extensions of the basic model}

So far, our model explains two major bodies of evidence that the existing model ignores: why most merchant guilds were local, and why rulers were willing to grant them exclusive local trading rights and other economic privileges in return for various forms of payment. We now go on to explain why rulers often welcomed the establishment of alien merchant guilds, why they were willing to grant them a variety of economic privileges in return for lump-sum payments and other forms of transfer, and why most international trade centers had multiple merchant guilds (a fact ignored by the GMW model).

\subsection{The evolution of ruler-guild relations and the role of alien guilds}

To examine the evolution of ruler-guild relations, consider the simplest possible extension of the basic model to a repeated game setting. Let the two-period model described in Section 3 represent the stage game in an infinitely repeated game. Thus in what follows each "period" $t$ will represent one realization of this stage game. The players' common discount factor is denoted by $\delta$. During each stage game, the random variable $\theta_{t}$ will be an independent random draw from the distribution described in Subsection 3.2; that is, $\theta_{t}$ takes the value $\theta_{L}$ with probability $\pi$ and $\theta_{H}$ with probability $1-\pi$.

The timing of the game is now as follows. At $t=0$, the ruler decides whether to grant recognition to a merchant guild and on what terms. We can model this as the offer of a long-term contract to a subset $S$ of merchants, specifying the privileges to be enjoyed by the guild (formed by this subset $S$ of merchants) in all subsequent periods $t(t=0,1, \ldots \infty)$, together with the transfers to be made by the guild to the ruler at the beginning $\left(y_{0 t}\right)$ and end $\left(y_{1 t}\right)$ of each period. The merchants can accept or refuse the offer. If they refuse, the ruler adopts the delegated taxation solution, which gives the merchants zero profits. If the offer is accepted, the game continues as specified in the contract, unless one of the two parties decides to deviate (see below).

In this setting, the first-best outcome from the ruler's ex ante $(t=0)$ point of view can be defined as one in which the ruler obtains utility $U^{F B}$ in every period $t$, implying that his ex ante expected utility is given by:

$U^{*}=\sum \delta^{t} U^{F B}=U^{F B} /(1-\delta)$.

Denote by $C_{0}$ the ruler's contractual offer to the subset $S$ of merchants at $t=0$, and let the variable $p_{t}$ take value 1 if the subset $S$ of merchants is established as a merchant guild in period $t$, with monopoly rights over local trade and the right to levy dues on members; otherwise $p_{t}$ takes value 0 . Thus a contract $C_{0}$ is defined 
as $C_{0}=\left\{p_{t}, y_{0 t}, y_{1 t}\right\}$ for $t=(0,1, \ldots, \infty)$.

The first-best outcome can be sustained as a subgame perfect equilibrium of the infinitely repeated game between the ruler and the merchants as long as players are sufficiently patient: ${ }^{47}$

Proposition 4 Suppose that the following condition holds:

$U^{F B} /(1-\delta) \geq L+U^{D M} /(1-\delta)$

Then the following strategies form a subgame perfect equilibrium of the infinitely repeated game between the ruler and the merchants: at $t=0$, the ruler offers the contract $C_{0}=\left\{p_{t}=1, y_{0 t}=L, y_{1 t}=T^{*}\left(\theta_{L}\right)\right\}$ for $t=(0,1, \ldots, \infty)$ to the subset $S$ of merchants. If the merchants accept and respect the agreement, the ruler respects the agreement. If the merchants refuse the agreement, the ruler adopts the delegated taxation solution. If, having accepted the agreement, the merchants deviate during any period $t$, the ruler withdraws their privileges and adopts the delegated taxation solution from then on. The merchants at $t=0$ accept any offer from the ruler that gives them non-negative expected profits. If the ruler respects the agreement, so do the merchants. If the ruler deviates from the agreement during any period $t$, the merchants refuse to cooperate from then on.

Proof: The payments profile implied by the contract $C_{0}$ gives the ruler expected utility $U^{*}$; the ruler cannot do better than this. Given the ruler's strategy, the merchants cannot do better than accept his offer $C_{0}$ at $t=0$. It remains to show that neither the ruler nor the guild can gain by deviating in any subsequent period $t$. Deviation by the guild entails non-payment (or partial payment) of either $L$ or $T^{*}\left(\theta_{L}\right)$. If the guild does not pay $L$ in full, the ruler withdraws its privileges and hires an agent to collect taxes; the guild therefore cannot benefit from such a deviation. The same is true if the guild does not pay in full $T^{*}\left(\theta_{L}\right){ }^{48}$ Deviation by the ruler entails withdrawing the guild's privileges and delegating tax collection to an agent just after the guild has paid $L$ in full. The gain from this deviation in period $t$ is $L+U^{D M}-U^{F B}$; the loss is the difference between $U^{F B}$ and $U^{D M}$ in all subsequent periods. Condition (C1) implies that the ruler

\footnotetext{
${ }^{47}$ For simplicity we abstract from the possibility of involuntary default by the guild - that is, the possibility that at the beginning of some period $t$ the guild may find itself with insufficient resources to make the payment $y_{0 t}$ (to the extent that the ruler cannot distinguish between voluntary and involuntary default, the latter will be punished in the same way as the former). Clearly if the likelihood of involuntary default is high, the first-best outcome is unlikely to be sustained in equilibrium over time. In practice this does not seem to have been a significant problem. Moreover, it is worth emphasizing that guilds were often able to provide non-financial assistance to the ruler (e.g. various forms of political support) which could substitute, at least partly, for financial transfers; evidence to this effect is presented below.

${ }^{48}$ We assume that the tax collector can always raise at least $T^{*}\left(\theta_{L}\right)-y_{1 t}$ in tax revenues, once given the power to do so by the ruler.
} 
cannot benefit from such a deviation. ${ }^{49}$

Proposition 4 shows that the first-best outcome, in which the ruler obtains the total expected surplus from trade while the guild makes zero expected profits, can be sustained in equilibrium over time as long as $\delta$ is not too low. How robust is this result?

We have assumed so far that the subset of merchants $S$ that forms the guild is smaller than the set of all merchants $A$ (which includes all agents potentially willing and able to act as merchants, i.e. to trade); indeed, this is what gave value to the guild's power to exclude non-members from trade (monopoly rights). This is consistent with available historical evidence, as discussed in Section 4.3 above.

However, once a guild was established and endowed with such monopoly rights, it typically used its power to try to become entrenched, eliminating or at any rate undermining potentially viable competitors so as to become the only credible player who could commit to providing the required levels of trade and regular sources of income for the ruler. ${ }^{50}$ To the extent that a merchant guild succeeded in undermining potential local competitors, it acquired some bargaining power relative to the ruler; it could then try to use this to obtain a share of the surplus from trade.

Going back to Proposition 4, notice that the ruler's "punishment" strategy, used to sustain the equilibrium, entails adopting the delegated monitoring solution, which gives the ruler per-period utility $U^{D M}$. However, if the guild is fully entrenched, it can withdraw from trade and thereby reduce the ruler's utility to zero (no trade, no revenue). The guild, once entrenched, might be able to use this fact to renegotiate the original contract in its favour (i.e. so as to make positive expected profits); clearly, the extent to which it will be able to do this depends on the nature of the bargaining (renegotiation) game between the ruler and the guild. In practice, given that medieval rulers' coercive powers were typically subject to substantial limitations (rulers often faced both financial and political constraints indeed merchant guilds played an important role in helping to alleviate both types of constraint, as will be discussed below), it seems highly likely that entrenched

\footnotetext{
${ }^{49}$ Notice also that if the ruler tries to deviate by taking $L$ from the existing guild, then withdrawing its privileges and offering to form a new guild with a different subset of merchants, the new subset of merchants will not be willing to make any ex ante payments to the ruler, for fear of suffering the same fate as the original guild. The ruler therefore could not gain from this type of deviation either.

${ }^{50}$ For example, in the course of the twelfth- and thirteenth-century conflicts between the merchant guild and craftsmen's guilds in the German city of Goslar, the merchant guild actually prevailed upon the ruler to outlaw all guilds (except that of the merchants themselves) in 1219; when this prohibition was lifted again in 1223, the two guilds that continued to be prohibited were those of the carpenters and linen-weavers, a decision that is regarded as reflecting the economic interests of the merchants in dominating local trade. See Frölich (1934).
} 
merchant guilds were indeed able to secure a significant share of the surplus from trade for themselves.

We therefore have the following implications for the evolution of ruler-guild relations over time. When guilds were first established, they were typically in no position to earn significant rents: more precisely, they did earn substantial rents from trade (monopoly profits), but these rents were used to obtain the continued support of rulers, without whom guild merchants could not have earned the rents in the first place. However, as time went by, those guilds that succeeded in becoming entrenched were able to acquire some bargaining power, which they used to obtain a share of the surplus from trade: the rents were then divided between rulers and guilds.

So far we have been referring to relations between each local ruler and the local guild. When a sufficiently well-organized guild of alien merchants arrives on the scene and tries to negotiate with the local ruler to obtain trading rights, this obviously affects the relative bargaining power of the local ruler and the local guild in their negotiations. To the extent that the alien guild represents a credible alternative to the local guild, the result is a decrease in the local guild's bargaining power, to the ruler's advantage. The implication is that, in many cases, the arrival of alien guilds should have been welcomed by local rulers, and opposed by local guilds.

Of course, in some cases the local guild may have been able to retain all its monopoly privileges - at a price. In other cases, the local guild's offer to the ruler may not have been sufficient to induce the ruler to turn down rival offers from alien guilds, partly because of differences in what each guild could provide, and partly because each guild's bilateral negotiations with the ruler must have taken place under conditions of asymmetric information (thus, for example, the local guild probably possessed better information concerning local trade, while each alien guild probably had superior knowledge of its own costs). In practice, negotiations could take place over "partial" monopoly privileges: rulers of international trade centers were typically able to grant a wide range of privileges, including exclusive rights to trade in particular commodities, in particular areas, to particular customers, with corresponding reductions in, or exemptions from, different taxes on trade. This would have been of considerable interest to rulers, since in most cases they were likely to have even less direct access to relevant information than the guilds. In particular, their information about the true value to the guilds of the different privileges they could grant them must have been obtained to a large extent indirectly, from the offers that guilds were willing to make to be given those privileges. This suggests that rulers should have been willing to grant different privileges to a different extent to different guilds, with periodic renegotiations, in order to elicit information about the (changing) value of privileges over time. 
We can therefore identify three key empirical implications of this section to be confronted with the historical evidence:

(1) Rulers welcomed the establishment of alien merchant guilds in their polities and granted them economic privileges. Local merchant guilds, on the other hand, objected to local rulers granting privileges to alien merchant guilds.

(2) Alien merchant guilds were able to levy dues from their members, which were used, at least partly, to make transfers to the ruler, in return for their privileges.

(3) Rulers granted different privileges to different guilds in return for different transfers, with periodic renegotiations. These privileges included reductions in trade taxes.

Once again, these empirical implications are strongly supported by the historical evidence.

\subsection{Historical evidence in support of our model}

We now review some of the abundant historical evidence which supports the implications outlined above; a wealth of additional detail is provided in Dessí and Ogilvie (2003).

(1) In the vast majority of documented cases, rulers welcomed the establishment of alien merchant guilds and granted them privileges. This occurred in polities as distant and different as Norway, ${ }^{51}$ Constantinople, ${ }^{52}$ Cyprus, ${ }^{53}$ and Jerusalem. ${ }^{54}$ The granting of such privileges to alien merchant guilds was typically opposed by the local merchant guild, whether it be in Denmark, ${ }^{55}$ Norway, ${ }^{56}$ Bruges, ${ }^{57}$ London, ${ }^{58}$ Danzig, ${ }^{59}$ or Bilbao. ${ }^{60}$ The privileges rulers granted to alien merchant guilds included rights to exercise monopolies over certain lines of business: specifically, they could exclude non-members from trade, limit membership numbers, exclude applicants with certain personal characteristics, and limit price and quantity competition among members. ${ }^{61}$

(2) Alien merchant guilds levied dues from their members and used them to

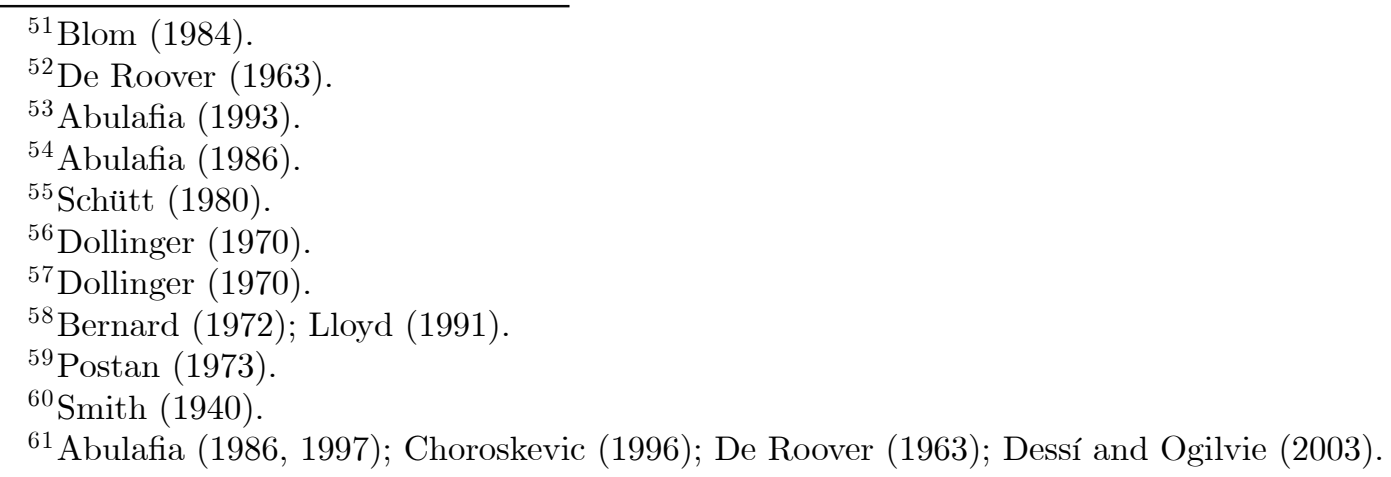


render financial payments and military assistance to rulers in return for the grant of economic privileges. This pattern is, again, observed in the majority of documented cases, in polities as diverse as Denmark, ${ }^{62}$ Russia,${ }^{63}$ Egypt,${ }^{64}$ Jerusalem, ${ }^{65}$ and Venice. ${ }^{66}$

(3) Rulers granted different privileges, including tax reductions, to different merchant guilds. Thus, for instance, from the eleventh to the fourteenth century, the rulers of Constantinople granted tax reductions to the merchants of (in descending order of the value of the exemptions) Venice, Genoa, Pisa, Catalonia, Narbonne, Ancona, Florence, and Ragusa. ${ }^{67}$

\subsection{Other benefits to the ruler}

The establishment of merchant guilds is likely to have brought other benefits to rulers, beyond the key benefit identified in Section 4, namely the opportunity to tax more efficiently. In this section we consider two other possible benefits to rulers.

\subsubsection{Financing constraints}

Medieval rulers could not easily borrow to finance their preferred investment projects, which included military campaigns, grand buildings, court display, and rewards to political allies. Regular and reliable payments from merchant guilds could help to alleviate these financing constraints. A further potential role in alleviating rulers' financial constraints emerges from our analysis of the evolution of relations between rulers and merchant guilds. To the extent that guilds were able to acquire some bargaining power vis-à-vis rulers, thereby securing some rents, they may also have become a valuable source of loans for rulers. This may have been the case for entrenched local guilds and also for powerful alien guilds. Merchant guilds possessing sufficient bargaining power (because the ruler would suffer a significant loss if they decided to boycott trade) would have been in a much better position to lend to rulers than most other possible creditors. The guilds' power may therefore have helped rulers when they needed to borrow but could not easily

\footnotetext{
${ }^{62}$ Hoffmann (1980).

${ }^{63}$ Choroskevic (1996).

${ }^{64}$ Abulafia (1995).

${ }^{65}$ Abulafia (1986; 1997).

${ }^{66}$ Choroskevic (1996); Kedar (1976).

${ }^{67}$ Balard (2000). For further evidence of the differential granting of privileges to alien merchant guilds, see Abulafia (1978) on the twelfth-century Kings of Sicily; Abulafia (1993) on the early fourteenth-century ruler of Cyprus; Hørby (1984) on the twelfth-century rulers of Utrecht; and De Roover (1963) on the thirteenth-century Kings of England.
} 
do so from other sources because it was difficult for them to commit (credibly) to repay.

The historical evidence shows that this was indeed the case. Both local and alien merchant guilds made very large loans to medieval rulers, ${ }^{68}$ who occupied "first place among their customers and consumers of credit". ${ }^{69}$ In return for supplying credit to rulers, merchant guilds and merchant companies received "legal privileges and exemption from export duties, the mortgaging of customs to them and the profits from rights of moneying". ${ }^{70}$

\subsubsection{Countervailing powers: merchants and the nobility}

In some cases, rulers may have benefited from the formation of merchant guilds because they enabled merchants to exercise some countervailing power to the (considerable) power held at the time by the landholding nobility. ${ }^{71}$ The historical evidence shows that medieval rulers did seek to diversify their sources of economic contributions and political support. The nobility was probably the most important source at the beginning of the medieval period. This gave it considerable power: for instance, the rulers of medieval Catalonia were constrained in their ability to expand extraordinary taxation by the power of the nobility, who preferred peasants to pay exactions to themselves as feudal dues. ${ }^{72}$

However, by the twelfth century at latest, merchant guilds were beginning to constitute another important constituency from which rulers could hope to derive political support as well as economic contributions. Thus, for instance, in the 1120s and 1130s King Roger of Sicily granted tax privileges to the merchant guilds of the Venetians and the Genoese in exchange for their political support against Emperor Lothar, while the merchant guild of the Pisans, who supported Lothar, had to pay normal taxes. ${ }^{73}$ There is also evidence that merchant guilds became valuable political allies for rulers vis-à-vis their own landholding nobility. ${ }^{74}$

\footnotetext{
${ }^{68}$ See Abulafia (1990); Bernard (1972); Carpenter (2000); Dessí and Ogilvie (2003); Dollinger (1970); Fryde (1958); Planitz (1940).

${ }^{69}$ Bernard (1972) (quotation); Spufford (2000).

${ }^{70}$ Bernard (1972).

${ }^{71}$ Dessí and Ogilvie (2003); Stephenson (1933).

${ }^{72}$ Bisson (1984).

${ }^{73}$ Abulafia (1978).

${ }^{74}$ In the twelfth and thirteenth centuries, the rulers of Flanders granted wide-ranging privileges to Flemish towns and the merchant guilds that dominated them in return for "financial aid, in their struggles against the still active nobility" (Blockmans (2000)). In the late thirteenth and early fourteenth century, the Catalan monarchy saw the overseas "consulates" formed by the Barcelona merchant guild in Tunis and Alexandria as "a major source of revenue which might enable the king to emancipate himself from dependency on internal taxation" - i.e., from the necessity of making political concessions to the landowning nobility represented in the
} 
Thus political support could be a valuable alternative form of "payment" to rulers by merchant guilds, as suggested in Section 5.1.

\section{Conclusions}

"Social capital" is widely advocated as the cure to many modern economic ills, and history is mined for examples of institutions that generate it. Merchant guilds are unquestionably economists' favourite example of an institution whose social capital benefited entire economies.

We question this rosy view of merchant guilds and social capital, and propose an alternative model which accords better with the empirical evidence. We identify four major bodies of evidence that are inconsistent with the existing view that merchant guilds emerged to enable rulers to guarantee security to long-distance merchants. First, most merchant guilds were local organizations of those trading in a particular city, enjoying economic privileges from local rulers; only a minority were active in long-distance trade; thus the commitment problems of alien rulers were irrelevant to most merchant guilds. Second, merchant guilds themselves created commercial insecurity for outsiders by attacking those whom they regarded as infringing their monopolies. Third, most international trade centers contained several merchant guilds, rendering guild boycotts of alien rulers ineffectual. Fourth, merchant guilds universally made transfers to rulers in return for economic privileges. The existing theory of merchant guilds is inconsistent with these stylized facts about merchant guilds.

We advance an alternative model of merchant guilds that better accounts for the facts, but has very different implications. Our theory argues that merchant guilds enabled rulers to tax trade much more efficiently. As we show, this fiscal advantage was the basis for a collusive relationship between rulers and merchant guilds which evolved to provide substantial mutual benefits - often to the detriment of other members of society.

Our theory explains not only the rise and behaviour of merchant guilds in medieval Europe, but also their disappearance. The prevailing GMW theory argues that merchant guilds disappeared at the end of the medieval period when rulers became better able to provide commercial security: "as the state system evolved, the need for the merchant guilds to secure merchants' rights declined". ${ }^{75}$ But this is inconsistent with the empirical findings. By 1550, the "military", "fiscal" and "bureaucratic" revolutions meant that most European rulers were more than

corts (Abulafia (2000)). In the late fifteenth century the ruler of Naples granted extensive tax reductions and monopolies to the Florentine merchant guild in return for large loans to help him quell a rebellion by his nobles (Abulafia (1990)).

${ }^{75}$ Greif et al. (1994). 
capable of guaranteeing commercial security in normal times. ${ }^{76}$ However, in most parts of Europe, merchant guilds did not disappear. True, in England and the Netherlands, merchant guilds did decline rapidly after about $1500 .{ }^{77}$ But this cannot have been because English and Dutch rulers had very precocious armies and bureaucracies - if anything, they lagged behind the "absolutist" rulers of the rest of the continent in these respects. Rather, England and the Netherlands were precocious in developing new fiscal methods - both taxation and borrowing - which freed them from financial dependence on the practice of granting economic privileges to favoured groups such as merchant guilds. ${ }^{78}$ By contrast, in France, Germany, Austria, Spain, and Italy, "absolutist" sovereigns satisfied their huge demand for revenues to fight wars and engage in court display by continuing to grant economic privileges to merchant guilds in return for lump-sum transfers throughout the sixteenth, seventeenth and eighteenth centuries. They only abolished merchant guilds in the eighteenth or nineteenth centuries when they developed alternative fiscal mechanisms. ${ }^{79}$

What implications does our alternative interpretation of this important medieval institution have for how we think about social capital more generally? Merchant guilds constituted closely knit "social networks" in which members transacted with one another repeatedly in a wide variety of different spheres of activity, thereby generating a "social capital" of shared norms, rapid and accurate transmission of information about members' actions, efficient punishment of deviations from group norms, and effective organization of collective action. But the norms they fostered, the information they conveyed, the deviance they punished, and the collective action they organized have disturbing implications for the impact of social capital on society as a whole. Merchant guilds colluded with rulers to obtain rents, which they then shared between them. Rulers may have allocated some of their share of these rents to providing public goods, but probably very little: all available evidence shows that pre-modern rulers spent the vast majority of their revenues on military activity and court display. ${ }^{80}$ Merchant guilds enjoyed their share of rents as supra-normal profits. Consumers were harmed by this exercise of social capital, since they paid a higher price for the traded goods supplied by monopolistic guilded merchants. Non-guilded merchants who were excluded from guild membership were harmed by this exercise of social capital, since they were prohibited from trading; often those excluded from merchant guilds constituted the less well-off members of society in any case (women, Jews, foreigners,

\footnotetext{
${ }^{76}$ Glamann (1974).

${ }^{77}$ Ogilvie (1997, 2003); Smith (1940).

${ }^{78}$ Brewer (1989); De Vries and Van der Woude (1997); Ogilvie (1997, 2003).

${ }^{79}$ Brewer (1989); Ogilvie (1997, 2003); Smith (1940).

${ }^{80}$ Brewer (1989).
} 
migrants, peasants). Finally, the economy at large was harmed by this exercise of social capital because, by acting as monopolists and raising prices, merchant guilds ensured that fewer transactions took place. These theoretical and empirical observations suggest strongly that economists must be willing to focus on the negative, as well as the positive, externalities of social capital.

\section{References}

Abulafia, David, "Pisan commercial colonies and consulates in twelfth-century Sicily", English Historical Review, 93 (1978), 68-81.

Abulafia, David, "The crown and the economy under Ferrante I of Naples (1458-94)", in Dean, Trevor, and Wickham, Chris (eds.), City and countryside in late medieval and Renaissance Italy: essays presented to Philip Jones (London, 1990), 125-46.

Abulafia, David, "The Anconitan privileges in the Kingdom of Jerusalem and the Levant trade of Ancona", in Airaldi, G., and Kedar, B. Z. (eds.), I comuni italiani nel regno crociato di Gerusalemme (Genova, 1986), 525-70.

Abulafia, David, "The Levant trade of the minor cities in the thirteenth and fourteenth centuries: strengths and weaknesses", Asian and African Studies, 22 (1988), 183-202.

Abulafia, David, "Trade and crusade, 1050-1250", in Goodich, Michael, Menache, Sophia, and Schein, Sylvia (eds.), Cross cultural convergences in the Crusader period (New York etc., 1995), 1-20.

Abulafia, David, "East and west: comments on the commerce of the city of Ancona in the Middle Ages", in Ghezzo, M. P. (ed.) Città e sistema adriatico alla fine del medioevo (Padua, 1997), 49-66.

Abulafia, David, "Grain traffic out of the Apulian ports on behalf of Lorenzo de'Medici, 1486-7", in Xuereb, Paul (ed.), Karissime Gotifride (Malta, 1999), 25-36.

Abulafia, David, "The rise of Aragon-Catalonia", in Abulafia, David (ed.), The new Cambridge medieval history, vol. V: c. 1198 - c. 1300 (Cambridge, 2000), 644-67.

Abulafia, David, "Narbonne, the lands of the Crown of Aragon, and the Levant trade 1187-1400", repr. in Abulafia, David (ed.), Commerce and conquest in the Mediterranean, 1100-1500 (Aldershot, Hampshire, 1993).

Bahr, K., Handel und Verkehr der Deutschen Hanse in Flandern während des vierzehnten Jahrhunderts (Leipzig, 1911).

Bardhan, Pranab. "The nature of institutional impediments to economic development" (March 3, 1996). Center for International and Development Eco- 
nomics Research Paper C96-066. http://repositories.cdlib.org/iber/cider/C96066 I.

Bateson, Mary (ed.), Records of the Borough of Leicester (London, 1899), vol.

Bernard, Jacques, "Trade and finance in the Middle Ages: 900 to 1500", in Cipolla, C. M., and Borchardt, Knut (eds.), The Fontana economic history of Europe, vol. I: The Middle Ages (London, 1972), 274-329.

Bisson, Thomas N., Fiscal accounts of Catalonia under the early Count-Kings (1151-1213) (Berkeley, 1984).

Blockmans, Wim, "Flanders", in Abulafia, David (ed.), The new Cambridge medieval history, vol. V: c. 1198 - c. 1300 (Cambridge, 2000), 405-18.

Blom, Grethe Authén, "Der Ursprung der Gilden in Norwegen und ihre Entwicklung in den Städten während des Mittelalters", in Friedland, Klaus (ed.), Gilde und Korporation in den nordeuropäischen Städten des späten Mittelalters (Köln/Wien, 1984), 5-28.

Bourdieu, Pierre, "The forms of capital", in Richardson, J. G. (ed.) Handbook of Theory and Research for the Sociology of Education (Westport, CT, 1986).

Brewer, John, The sinews of power: war, money and the English state, 16881783 (London, 1989).

Carpenter, D. A., "The Plantagenet kings", in Abulafia, David (ed.), The new Cambridge medieval history, vol. V: c. 1198 - c. 1300 (Cambridge, 2000), 314-57.

Choroskevic, Anna Leonidovna, "Der deutsche Hof in Novgorod und die deutsche Herberge in Venedig im 13./14. Jahrhundert. Eine vergleichende Vorstudie", in Pelc, Ortwin, and Pickhan, Gertrud (eds.), Zwischen Lübeck und Novgorod (Lüneburg, 1996), 67-87.

Coleman, James S., "Social capital in the creation of human capital", American Journal of Sociology, 94 (1988), S95-S121.

Coleman, James S., Foundations of social theory (Cambridge, MA, 1990).

Daenell, E. R., Die Blütezeit der deutschen Hanse, 2 vols. (Berlin, 1905).

Dasgupta, P., "Economic progress and the idea of social capital", in Dasgupta, P., and Serageldin, I. (eds.), Social capital: a multifaceted perspective (Washington, 2000), 325-424.

Dasgupta, P., and Serageldin, I. (eds.), Social capital: a multifaceted perspective (Washington, 2000).

De Roover, Raymond, "The organization of trade", in Postan, M. M., Rich, E. E., and Miller, Edward (eds.), The Cambridge economic history of Europe, vol. III: Economic organization and policies in the Middle Ages (Cambridge, 1963), 42-118.

Dessí, Roberta, and Ogilvie, Sheilagh, "Social capital and collusion: the case of merchant guilds (long version)", Working Paper (2003), University of Cambridge. 
http://www.econ.cam.ac.uk/faculty/ogilvie/dessi-ogilvie-long.pdf

De Vries, Jan, and Van der Woude, Ad, The first modern economy: success, failure, and perseverance of the Dutch economy, 1500-1815 (Cambridge, 1997).

Dilcher, Gerhard, "Die genossenschaftliche Struktur von Gilden und Zünften", in Schwineköper, Berent (ed.), Gilden und Zünfte (Sigmaringen, 1985), 71-112.

Dollinger, Philippe, The German Hansa (Stanford, 1970).

Ehbrecht, Wilfried, "Beiträge und Überlegungen zu Gilden im nordwestlichen Deutschland (vornehmlich im 13. Jahrhundert)", in Schwineköper, Berent (ed.), Gilden und Zünfte (Sigmaringen, 1985), 413-50.

Epstein, Stephan R., An island for itself: economic development and social change in late medieval Sicily (Cambridge, 1992).

Epstein, Steven A., "Urban society", in Abulafia, David (ed.), The new Cambridge medieval history, vol. V: c. 1198 - c. 1300 (Cambridge, 2000), 26-37.

Freshfield, E. H., Roman Law in the later Roman Empire: Byzantine guilds, professional and commercial. Ordinances of Leo VI c. 895 from the Book of the Eparch (Cambridge, 1938).

Frölich, K., "Kaufmannsgilden und Stadtverfassung im Mittelalter", in Merk, Walther (ed.), Festschrift Alfred Schultze zum 70. Geburtstag (Weimar, 1934), $85-128$.

Fryde, E. B., "The English farmers of the Customs, 1343-51", Transactions of the Royal Historical Society, 5th series, 9 (1959), 1-18.

Fryde, Natalie, "Gilds in England before the Black Death", in Schwineköper, Berent (ed.), Gilden und Zünfte (Sigmaringen, 1985), 215-30.

Glaeser, Edward L., Laibson, David, and Sacerdote, Bruce, "An economic approach to social capital", Economic Journal, 112 (2002), 437-58.

Glamann, Kristof, "European trade, 1500-1750", in Cipolla, Carlo M. (ed.), The Fontana economic history of Europe, vol. 2: The sixteenth and seventeenth centuries (Glasgow, 1974), 427-526.

González de Lara, Y., "Institutions for contract enforcement and risk-sharing: from debt to equity in late medieval Venice", unpublished paper (Ente Einaudi, 2001).

Greif, A., Milgrom, P., and Weingast, B. R., "Coordination, commitment, and enforcement: the case of the merchant guild", Journal of Political Economy, 102 (1994), 745-76.

Hibbert, A. B., "The economic policies of towns", in Postan, M. Michael, Rich, E. E., and Miller, Edward (eds.), The Cambridge economic history of Europe, vol. III, Economic organization and policies in the Middle Ages (Cambridge, 1963), 157-229.

Hlavácek, Ivan, "The Luxemburgs and Rupert of the Palatinate, 1347-1410", in Jones, Michael (ed.), The new Cambridge medieval history, vol. VI: c. 1300 - 
c. 1415 (Cambridge, 2000), 551-69.

Hoffman, E., "Beiträge zur Geschichte der Stadt Schleswig und des westlichen Ostseeraums im 12. und 13. Jahrhundert", Zeitschrift der Gesellschaft für Schleswig-Holsteinische Geschichte, 105 (1980), 27-76.

Hørby, Kai, "Königliche-dänische Kaufleute. Dänische Wanderkaufleute des frühen Mittelalters, ihre korporative Organisation und ihre Beziehungen zu dänischen Städten, Handelszentren und Märkten”, in Friedland, Klaus (ed.), Gilde und Korporation in den nordeuropäischen Städten des späten Mittelalters (Köln/Wien, 1984), 41-50.

Irsigler, Franz, "Zur Problematik der Gilde- und Zunftterminologie", in Schwineköper, Berent (ed.), Gilden und Zünfte (Sigmaringen, 1985), 53-70.

Johanek, Peter, "Merchants, markets and towns", in Reuter, Timothy (ed.), The new Cambridge medieval history, Vol. 3: c. 900-c. 1024 (Cambridge, 1999), 64-94.

Kedar, B. Z., Merchants in crisis: Genoese and Venetian men of affairs and the fourteenth-century depression (New Haven, Conn., 1976).

Klein, Julius, "Medieval Spanish gilds", in Gay, E. F. (ed.), Facts and factors in economic history (Cambridge, MA, 1932), 164-88.

Kuske, Bruno, "Der Kölner Stapel und seine Zusammenhänge als wirtschaftspolitisches Beispiel", Jahrbuch des Kölnischen Geschichtsvereins, 21 (1939), 1-46.

Laiou, Angeliki E., "The Byzantine empire in the fourteenth century", in Jones, Michael (ed.), The new Cambridge medieval history, vol. VI: c. $1300-c$. 1415 (Cambridge, 2000), 795-824.

Leguay, Jean-Pierre, "Urban life", in in Jones, Michael (ed.), The new Cambridge medieval history, vol. VI: c. 1300 - c. 1415 (Cambridge, 2000), 102-25.

Lin, Nan, Social capital: a theory of social structure and action (Cambridge, 2001).

Lloyd, T. H., England and the German Hanse, 115\%-1611: a study of their trade and commercial diplomacy (Cambridge, 1991).

Lopez, Robert S., "European merchants in the medieval Indies: the evidence of commercial documents", Journal of Economic History, 3 (1943), 164-84.

Ogilvie, Sheilagh, State corporatism and proto-industry: the Württemberg Black Forest, 1580-1797 (Cambridge, 1997).

Ogilvie, Sheilagh, A bitter living: women, markets, and social capital in early modern Germany (Oxford, 2003).

Planitz, Hans, "Kaufmannsgilde und städtische Eidgenossenschaft in niederfränkischen Städten im 11. und 12. Jahrhundert", Zeitschrift der Savigny-Stiftung für Rechtsgeschichte, germanistische Abteilung, 60 (1940), 1-116.

Postan, M. M., "The economic and political relations of England and the Hanse from 1400 to 1475", Medieval trade and finance (Cambridge, 1973), 232-304. 
Prevenier, Walter, "The Low Countries, 1290-1415", in Jones, Michael (ed.), The new Cambridge medieval history, vol. VI: c. 1300 - c. 1415 (Cambridge, 2000), 570-94.

Pryor, John H., "The Maritime Republics", in Abulafia, David (ed.), The new Cambridge medieval history, vol. V: c. 1198 - c. 1300 (Cambridge, 2000), 419-46.

Putnam, Robert D., Bowling alone: the collapse and revival of American community (New York, 2000).

Putnam, Robert D., Leonardi, R., and Nanetti, R. Y., Making democracy work: civic traditions in modern Italy (Princeton, NJ, 1993).

Racine, P., "Associations de marchands et associations de métiers en Italie de 600 à 1200", in Schwineköper, Berent (ed.), Gilden und Zünfte (Sigmaringen, 1985), 127-50.

Raiser, Martin, "Informal institutions, social capital and economic transition", in Cornia, Giovanni Andrea, and Popov, Vladimir (eds.), Transition and institutions. the experience of gradual and late reformers (Oxford, 2001), 218-39.

Reyerson, Kathryn, "Commerce and communications", in Abulafia, David (ed.), The new Cambridge medieval history, vol. V: c. 1198 - c. 1300 (Cambridge, 2000), 50-70.

Schultze, Alfred, "Über Gästerecht und Gastgerichte in den deutschen Städten des Mittelalters", Historische Zeitschrift, 101 (1908), 473-528.

Schulz, Knut, "Patriziergesellschaften und Zünfte in den mittel- und oberrheinischen Bischofsstädten", in Schwineköper, Berent (ed.), Gilden und Zünfte (Sigmaringen, 1985), 311-36.

Schulze, Hans K., "Kaufmannsgilde und Stadtentstehung im mitteldeutschen Raum", in Schwineköper, Berent (ed.), Gilden und Zünfte (Sigmaringen, 1985), $377-412$.

Schütt, Hans-Friedrich, "Gilde und Stadt", Zeitschrift der Gesellschaft für Schleswig-Holsteinische Geschichte, 105 (1980), 77-136.

Smith, R. S., The Spanish guild merchant: a history of the consulado, 12501700 (Durham, NC, 1940).

Sobel, Joel, "Can we trust social capital?", Journal of Economic Literature, 40 (2002), 139-54.

Spufford, Peter, "Trade in fourteenth-century Europe", in Jones, Michael (ed.), The new Cambridge medieval history, vol. VI: c. 1300 - c. 1415 (Cambridge, 2000), 155-208.

Stephenson, C., Borough and town. A study of urban origins in England (Cambridge, MA, 1933).

Stiglitz, J., "New bridges across the chasm: institutional strategies for the transition economies" (World Bank, 8 Dec. 1999). http://wbln0018.worldbank.org/ eca/eca.nsf/0/0ac8adc7b03aca0885256847004e2b82?OpenDocument 
Theuerkauf, Gerhard, "Binnen- und Seehandel zur Hansezeit an mecklenburgischen Beispielen", in Pelc, Ortwin, and Pickhan, Gertrud (eds.), Zwischen Lübeck und Novgorod (Lüneburg, 1996), 179-89.

Volckart, O., and Mangels, A., "Are the roots of the modern lex mercatoria really medieval?", Southern Economic Journal, 65 (1999), 427-50. 


\section{Appendix}

\section{Proof of Proposition 1}

In any given state of nature $\theta$, the tax rate that maximizes tax revenues has the following two properties: (a) it induces the same level of trade, $q^{*}(\theta)$, which would be chosen by a profit-maximizing monopolist facing a constant marginal cost of production $c$; (b) it leaves exactly zero profits to the (competitive) merchants. We can therefore obtain the optimal tax rate, $\tau^{*}(\theta)$, by first solving the monopolist's problem to find $q^{*}(\theta)$, and then noting that, by property (b) above, we must have:

$$
\left(1-\tau^{*}(\theta)\right) P\left(q^{*}(\theta)\right)=c
$$

The monopolist would choose $q^{*}(\theta)$ such that:

$$
q^{*}=\arg \max [\theta(a-b q)-c] q
$$

which yields the solution:

$$
q^{*}(\theta)=\frac{a \theta-c}{2 b \theta}
$$

The price is then given by:

$$
P\left(q^{*}(\theta)\right)=\theta\left[a-b q^{*}(\theta)\right]=\frac{a \theta+c}{2}
$$

From (8.1) and (8.4), we obtain the optimal tax rate:

$$
\tau^{*}(\theta)=1-\frac{c}{P\left(q^{*}(\theta)\right)}=\frac{a \theta-c}{a \theta+c}
$$

and hence total tax revenues:

$$
T^{*}(\theta)=\tau^{*} P\left(q^{*}\right) q^{*}=\frac{(a \theta-c)^{2}}{4 b \theta}
$$

\section{Proof of Proposition 2}

To begin with, we need to derive $T^{\circ}(\tau, \theta)$, the total tax revenue the agent can collect in state $\theta$ by applying the tax rate $\tau$. This will be given by:

$$
T^{\circ}(\tau, \theta)=\tau P(\tau, \theta) q(\tau, \theta)
$$

where $P(\tau, \theta)$ and $q(\tau, \theta)$ are the equilibrium price and quantity traded in state 
$\theta$ when the tax rate is $\tau$. Merchants will trade up to the point where marginal revenue equals marginal cost, i.e. $P(1-\tau)=c$. Using this condition, we obtain:

$$
\begin{gathered}
P(\tau, \theta)=\frac{c}{1-\tau} \\
q(\tau, \theta)=\frac{a}{b}-\frac{c}{b \theta(1-\tau)}
\end{gathered}
$$

Assume the ruler can observe the tax rate $\tau$ applied by the agent, but not the true state of nature $\theta$, nor realized values of $q, P$ and $T$. Let the ex-ante agreement between the ruler and the agent specify the following:

- the tax rate to be applied by the agent in state $\theta_{i}(i=H, L), \tau_{i}$;

- the transfer to be made by the agent to the ruler in state $\theta_{i}(i=H, L), t_{i}$.

The ruler chooses $\tau_{i}, t_{i}(i=H, L)$ to maximize his expected revenue subject to two types of constraint: the agent should be induced to reveal truthfully the state of nature $\theta$ (incentive compatibility constraint), and he should be able to raise sufficient revenues from taxation to pay the required transfer (feasibility or limited liability constraint). The ruler's problem is given by:

$$
\begin{gathered}
\text { Max } \quad \pi t_{L}+(1-\pi) t_{H} \\
\text { s.t. } \quad T^{\circ}\left(\tau_{H}, \theta_{H}\right)-t_{H} \geq T^{\circ}\left(\tau_{L}, \theta_{H}\right)-t_{L} \quad\left(I C C_{H}\right) \\
T^{\circ}\left(\tau_{L}, \theta_{L}\right)-t_{L} \geq T^{\circ}\left(\tau_{H}, \theta_{L}\right)-t_{H} \quad\left(I C C_{L}\right) \\
T^{\circ}\left(\tau_{H}, \theta_{H}\right)-t_{H} \geq 0 \quad\left(L L_{H}\right) \\
T^{\circ}\left(\tau_{L}, \theta_{L}\right)-t_{L} \geq 0 \quad\left(L L_{L}\right)
\end{gathered}
$$

The binding constraints are $I C C_{H}$ and $L L_{L}$, while $I C C_{L}$ and $L L_{H}$ can be neglected. Thus:

$$
\begin{gathered}
t_{L}=T^{\circ}\left(\tau_{L}, \theta_{L}\right) \\
t_{H}=T^{\circ}\left(\tau_{H}, \theta_{H}\right)-T^{\circ}\left(\tau_{L}, \theta_{H}\right)+T^{\circ}\left(\tau_{L}, \theta_{L}\right)
\end{gathered}
$$

and the ruler's problem can be written more simply as: 


$$
\operatorname{Max} \pi T^{\circ}\left(\tau_{L}, \theta_{L}\right)+(1-\pi)\left[T^{\circ}\left(\tau_{H}, \theta_{H}\right)-T^{\circ}\left(\tau_{L}, \theta_{H}\right)+T^{\circ}\left(\tau_{L}, \theta_{L}\right)\right]
$$

Clearly the ruler can set $\tau_{H}$ so as to maximize $(1-\pi) T^{\circ}\left(\tau_{H}, \theta_{H}\right)$, which implies setting the tax rate at its first-best level in state $\theta_{H}$ :

$$
\tau_{H}=\tau_{H}^{*}
$$

The ruler then has to choose $\tau_{L}$ to maximize the following expression:

$$
L=\pi T^{\circ}\left(\tau_{L}, \theta_{L}\right)+(1-\pi)\left[T^{\circ}\left(\tau_{L}, \theta_{L}\right)-T^{\circ}\left(\tau_{L}, \theta_{H}\right)\right]
$$

Using (8.7), this becomes:

$$
L=\tau_{L}\left[P\left(\tau_{L}, \theta_{L}\right) q\left(\tau_{L}, \theta_{L}\right)-(1-\pi) P\left(\tau_{L}, \theta_{H}\right) q\left(\tau_{L}, \theta_{H}\right)\right]
$$

which, after some manipulation, can be written as:

$$
L=\frac{\tau_{L} \pi a c}{b\left(1-\tau_{L}\right)}-\frac{\tau_{L} \alpha c^{2}}{b\left(1-\tau_{L}\right)^{2}}
$$

where

$$
\alpha=\frac{1}{\theta_{L}}-\frac{(1-\pi)}{\theta_{H}}>0
$$

The first-order condition with respect to $\tau_{L}$ then gives:

$$
\tau_{L}=\frac{\pi a-\alpha c}{\pi a+\alpha c}<\tau_{L}^{*}
$$

Thus in state $\theta_{L}$ the tax rate is set below its first-best level, implying that:

$$
T^{\circ}\left(\tau_{L}, \theta_{L}\right)<T^{\circ}\left(\tau_{L}^{*}, \theta_{L}\right)
$$

i.e. tax revenues are not maximized in state $\theta_{L}$.

In state $\theta_{H}$ tax revenues are maximized, so that

$$
T^{\circ}\left(\tau_{H}, \theta_{H}\right)=T^{\circ}\left(\tau_{H}^{*}, \theta_{H}\right)
$$

but the ruler receives only a part of the taxes collected:

$$
t_{H}=T^{\circ}\left(\tau_{H}, \theta_{H}\right)-\left[T^{\circ}\left(\tau_{L}, \theta_{H}\right)-T^{\circ}\left(\tau_{L}, \theta_{L}\right)\right]<T^{\circ}\left(\tau_{H}, \theta_{H}\right)
$$

The ruler's expected utility is equal to: 


$$
U^{D M}=\pi T^{\circ}\left(\tau_{L}, \theta_{L}\right)+(1-\pi)\left[T^{\circ}\left(\tau_{H}, \theta_{H}\right)-T^{\circ}\left(\tau_{L}, \theta_{H}\right)+T^{\circ}\left(\tau_{L}, \theta_{L}\right)\right]
$$

which can be compared to the first-best level given by:

$$
U^{F B}=\pi T^{\circ}\left(\tau_{L}^{*}, \theta_{L}\right)+(1-\pi) T^{\circ}\left(\tau_{H}^{*}, \theta_{H}\right)>U^{D M}
$$

